\title{
Experts' recommendations for the management of cardiogenic shock in children
}

\author{
Olivier Brissaud ${ }^{1 *}$, Astrid Botte ${ }^{2}$, Gilles Cambonie ${ }^{3}$, Stéphane Dauger ${ }^{4}$, Laure de Saint Blanquat $^{5}$, \\ Philippe Durand ${ }^{6}$, Véronique Gournay ${ }^{7}$, Elodie Guillet ${ }^{1}$, Daniela Laux ${ }^{8}$, Francis Leclerc ${ }^{2}$, Philippe Mauriat ${ }^{9}$, \\ Thierry Boulain ${ }^{10}$ and Khaldoun Kuteifan ${ }^{11}$
}

\begin{abstract}
Cardiogenic shock which corresponds to an acute state of circulatory failure due to impairment of myocardial contractility is a very rare disease in children, even more than in adults. To date, no international recommendations regarding its management in critically ill children are available. An experts' recommendations in adult population have recently been made (Levy et al. Ann Intensive Care 5(1):52, 2015; Levy et al. Ann Intensive Care 5(1):26, 2015). We present herein recommendations for the management of cardiogenic shock in children, developed with the grading of recommendations' assessment, development, and evaluation system by an expert group of the Groupe Francophone de Réanimation et Urgences Pédiatriques (French Group for Pediatric Intensive Care and Emergencies). The recommendations cover four major fields of application such as: recognition of early signs of shock and the patient pathway, management principles and therapeutic goals, monitoring hemodynamic and biological variables, and circulatory support (indications, techniques, organization, and transfer criteria). Major principle care for children with cardiogenic shock is primarily based on clinical and echocardiographic assessment. There are few drugs reported as effective in childhood in the medical literature. The use of circulatory support should be facilitated in terms of organization and reflected in the centers that support these children. Children with cardiogenic shock are vulnerable and should be followed regularly by intensivist cardiologists and pediatricians. The experts emphasize the multidisciplinary nature of management of children with cardiogenic shock and the importance of effective communication between emergency medical assistance teams (SAMU), mobile pediatric emergency units (SMUR), pediatric emergency departments, pediatric cardiology and cardiac surgery departments, and pediatric intensive care units.
\end{abstract}

\section{Background}

Cardiogenic shock is an acute state of circulatory failure due to impairment of myocardial contractility. In children, the clinical signs of cardiac failure are tachycardia, dyspnea, and hepatomegaly, together with global signs related to a decrease of cardiac output. Cardiogenic shock represents $5-13 \%$ of diagnosed cases of shock in pediatric emergencies $[3,4]$. It is the most advanced and most serious stage of heart failure. In hospitalized children, cardiogenic shock is lethal in 5-10\% of cases, a mortality rate similar to that observed in adults $[5,6]$. Extracardiac

\footnotetext{
*Correspondence: Olivier.brissaud@chu-bordeaux.fr

1 Unité de Réanimation Pédiatrique et Néonatale, Hôpital des Enfants, CHU Pellegrin Enfants, Place Amélie Raba Léon, 33000 Bordeaux, France Full list of author information is available at the end of the article
}

comorbidities (such as sepsis, acute kidney failure, and liver failure) can lead to a fivefold increase of the mortality rate $[5,6]$. The following causes of heart failure are the most likely to lead to cardiogenic shock [5-10]: primary or secondary cardiomyopathy, acute or fulminant myocarditis, arrhythmia, congenital heart disease (whether surgically managed or not), postoperative period after cardiac surgery, and, in exceptional cases, endocarditis, rheumatic fever, severe Kawasaki disease, stress cardiomyopathy (Tako-Tsubo), valve cord rupture, drug or toxic substance intoxication. Cardiogenic shock can also be caused by extracardiac diseases (sepsis-induced myocardial failure, pulmonary embolization, pneumothorax, tamponade). Mortality is directly related to the underlying disease: congenital heart disease, rhythm disorders, acquired heart diseases, and cardiomyopathies, in 4.7, 23,

\section{照 Springer}

(c) 2016 Brissaud et al. This article is distributed under the terms of the Creative Commons Attribution 4.0 International License (http://creativecommons.org/licenses/by/4.0/), which permits unrestricted use, distribution, and reproduction in any medium, provided you give appropriate credit to the original author(s) and the source, provide a link to the Creative Commons license, and indicate if changes were made. 
8.7 , and $25 \%$ of children, respectively $[8,11]$. Mortality in case of decompensation is similar in children and adults. This is related to the fact that children also have other comorbidities but different from those of adults.

Management and monitoring of cardiogenic shock in childhood differ between anatomically normal heart and congenital heart disease. Recommendations made in this document are addressed to children without congenital heart disease; it is important in the case of children with heart disease who decompensates to be in contact with pediatric cardiologists to optimize management. Cardiogenic shock occurs when heart and circulation are no longer able to adapt to the situation and is characterized by severely impaired myocardial contractility, increased preload, severely impaired myocardial compliance, increased afterload, and an abnormally and persistently high heart rate. Decompensation may occur and manifests as a drop in blood pressure and/or cardiac output with inadequate tissue perfusion, as this is the final goal of cardiovascular performance, and the onset of anaerobic metabolism with the production of lactic acid. Unless treated, cardiogenic shock leads to multiple organ failure then progresses rapidly to death.

Even if the literature is poor regarding strong evidences in management of cardiogenic shock, we report, in this article, recommendations built by pediatricians and anesthesiologists, experts in the topic of cardiogenic shock. Process of recommendations' elaboration permitted us to avoid making the recommendations only based on own experience. The recommendations cover four major fields of application such as: recognition of the early signs of shock and the patient pathway, management principles and therapeutic goals, monitoring hemodynamic and biological variables, and circulatory support (indications, techniques, organization, and transfer criteria).

\section{Field of application 1: recognizing the early signs of shock}

Three pathophysiological states have been described for cardiogenic shock (Fig. 1):

Cold and wet: reduced myocardial contractility and increased left ventricular filling pressure (systolic and diastolic dysfunction).

Cold and dry: reduced myocardial contractility and low left ventricular filling pressure (systolic dysfunction).

Warm and wet: normal myocardial contractility and high left ventricular filling pressure (diastolic dysfunction).

\section{Clinical signs (Table 1)}

Impaired consciousness, arterial hypotension, and respiratory distress with a fall in oxygen saturation are the early signs of decompensated heart failure and cardiogenic shock [12-14].

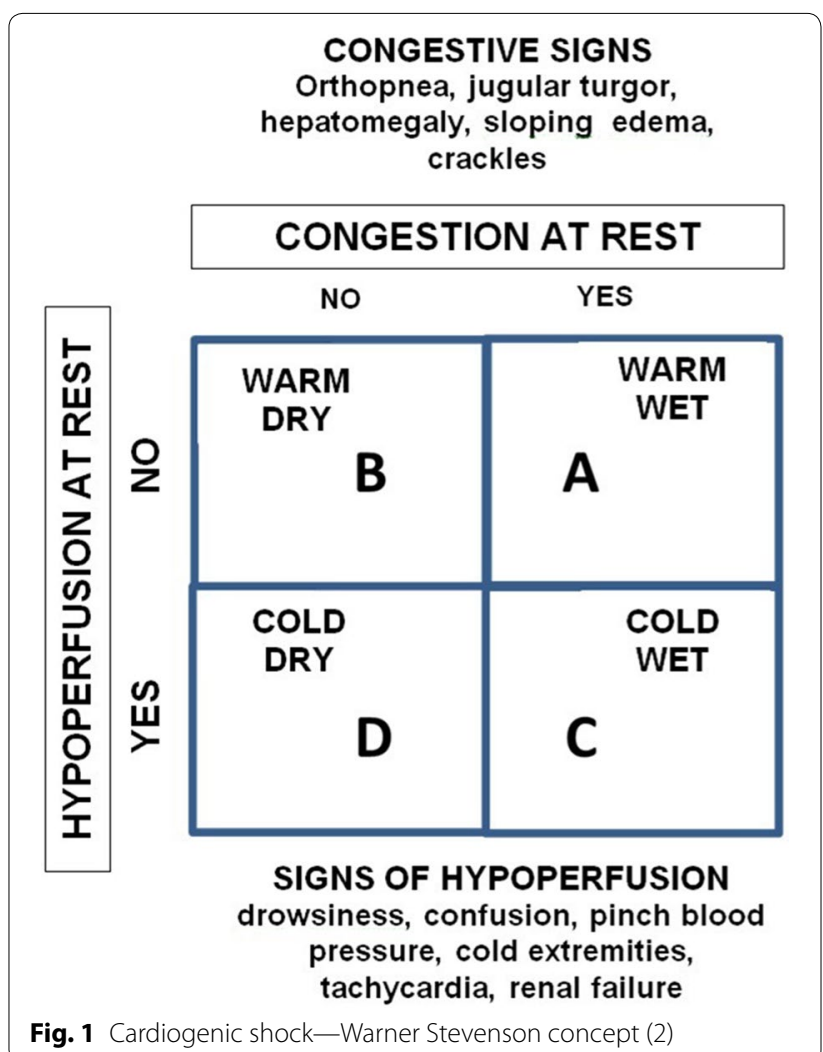

Table 1 Nonspecific clinical signs of cardiogenic shock in children

\begin{tabular}{ll}
\hline General & Default weight gain, asthenia \\
& Whiteness, sweating (diaphoresis) marbling ends \\
Hemodynamics & Tachycardia, edema \\
& Decreased peripheral pulses \\
& Heart murmur, gallop rhythm \\
& Bradycardia, arrhythmia \\
& Jugular turgor \\
& Polypnea or bradypnea; crackles \\
Respiratory & Cyanosis of the extremities or peri-oral \\
& Anxiety, restlessness \\
Neurological & Confusion \\
& Drowsiness \\
& Convulsions \\
& Coma \\
Hepatomegaly & Decreased transit \\
Kigestive & Food difficulties (polypnea, sweating during feeding) \\
& Oliguria \\
& Anuria \\
\end{tabular}

\section{Etiological signs}

Such signs are based on the patient's medical/surgical history (heart disease, systemic disease, long-term heart failure), but also on blood pressure measurements in all limbs, as well as the presence of heart murmur, arrhythmia, or sepsis. 


\section{Para-clinical signs}

Chest X-rays (cardiomegaly, pulmonary edema), ECGs (arrhythmia, myocardial ischemia, conduction disorders, drugs effect, changes in the QT interval), and transthoracic echocardiograms are useful for diagnostic, etiological, therapeutic, and prognostic purposes.

\section{Complications}

In addition to the risk of multiple organ failure and death, cardiogenic shock is sometimes associated with cardiorenal syndrome (oliguria, increased urea and creatinine levels concomitant with myocardial failure), which leads to longer hospital stays, the need for circulatory support, and an increased death rate [15].

\section{First-line treatment $[12,13,16-18]$}

The aim of initial patient management is to restore adequate oxygen delivery to peripheral tissues. This relies on emergency support (early recognition, monitoring, access), optimizing ventilation/gas exchange (oxygen therapy \pm noninvasive or invasive ventilation with a saturation objective of $>95 \%$ except in cyanotic heart disease patients), optimizing the preload and afterload (volume expansion or diuretics and fluid restriction, inotropes, discontinuation of deleterious medication), and treating curable causes (fluid and electrolyte balance, rhythm, or thromboembolic disorders; pneumothorax, tamponade, infection).

\section{Field of application 2: patient pathway, management principles, and therapeutic goals Patient pathway}

- All patients with cardiogenic shock should be transferred to PICU (strong agreement).

- Children with cardiogenic shock should be managed by a chain of specialized medical teams which adapt their care to the real or potential gravity of the patient throughout his/her stay in care. This medical chain should be clearly identified by all healthcare actors (SAMU, SMUR, pediatric emergency departments, pediatric cardiology and cardiac surgery departments, and PICU) (strong agreement).

- A telephone hotline to an "expert center" providing specialized responses should be available 24/24 (strong agreement).

- It is strongly advised that regional health agencies officially designate "expert centers" (strong agreement).

- The following multidisciplinary expertise should be available in such expert centers: pediatric medical and interventional cardiology, pediatric anesthesia, pediatric thoracic, vascular and cardiac surgery, pediatric intensive care, radiology (notably for interventional vascular procedures), mobile circulatory support unit (strong agreement).
Does prehospital care such as European pediatric life support improve the prognosis of cardiogenic shock?

- Basic or advanced European pediatric life support resuscitation, either prior to arrival or at the hospital should be used to reduce morbidity and mortality of cardiogenic shock (strong agreement).

- It is probably not advisable to use high doses of adrenaline $(\geq 30 \mu \mathrm{g} / \mathrm{kg})$ during resuscitation compared with usual doses (strong agreement).

- Early goal-directed therapy should be based on clinical (diuresis, preload, blood pressure) and laboratory (blood pH, lactate levels, continuous venous oxygen saturation) variables as well as echocardiogram (strong agreement).

- Once the acute phase of cardiogenic shock has been relieved, the patient should be prescribed appropriate oral therapy to treat cardiac insufficiency and should be closely monitored (strong agreement).

For non-trauma-related cardiogenic shock, "advanced pediatric life support" is associated with reduced mortality [OR $0.58(0.4-0.84)$ ] and functional morbidity [OR $0.13(0.04-0.41)$ ] [19]. No benefit has been observed when high doses of adrenaline $(0.1 \mathrm{mg} / \mathrm{kg}$ IV) are injected compared with usual doses $(0.01 \mathrm{mg} / \mathrm{kg}$ IV) during prehospital or hospital management of cardiac arrest $[20,21]$. Implementing therapeutic goals during shock management improves patient survival, notably for septic shock $[22,23]$.

\section{Medications}

Usefulness of fluid resuscitation in cardiogenic shock

- Fluid resuscitation should only be indicated in patients with cardiogenic shock after clinical assessment (preload insufficiency); it is advised that echocardiographic evaluation be used during such assessment (strong agreement).

- Fluid resuscitation with colloids and/or crystalloids should not be used in patients with cardiogenic shock (strong agreement).

In the FEAST study, despite specific comorbid conditions compared to those seen in industrialized countries, the increased mortality of children receiving fluid boluses was found to be due to cardiac events (cardiogenic shock) related to fluid overload [24].

\section{Usefulness of diuretics in the management of cardiogenic shock}

- In children with fluid overload and ventricular dysfunction, diuretics (such as furosemide) should be used to return to euvolemic state while monitoring 
clinical criteria and measuring the cardiac output (low level of evidence, strong agreement).

- It is probably not advisable to use venous perfusions of nesiritide (recombinant BNP) in children with cardiogenic shock (strong agreement).

- It is probably not advisable to use tolvaptan, a selective antagonist of the arginine vasopressin receptors (V2) that is given orally in children with cardiogenic shock (strong agreement).

In children with heart failure already treated with one or more inotropes and a loop diuretic, continuous perfusion of $0.005-0.02 \mu \mathrm{g} / \mathrm{kg} / \mathrm{min}$ nesiritide improves the fluid balance and reduces pressure in the right atrium

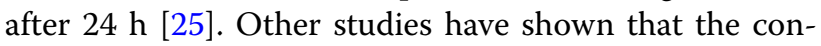
tinuous perfusion of $0.01-0.03 \mu \mathrm{g} / \mathrm{kg} / \mathrm{min}$ nesiritide improves echocardiogram variables (heart rate, left ventricular ejection fraction) and laboratory values (decreased creatinine, BNP and aldosterone levels) after $72 \mathrm{~h}$ [26]. In a retrospective series of 28 children with heart failure and hyponatremia, tolvaptan, a selective non-peptide antagonist the arginine vasopressin receptors (V2), improved, when used orally at a dose of $0.3 \mathrm{mg} /$ $\mathrm{kg}$, both diuresis and sodium levels after $72 \mathrm{~h}$ [27].

\section{Usefulness of inotropes in the management of cardiogenic shock}

- Dobutamine should be used at a dose of 5-20 $\mu \mathrm{g} / \mathrm{kg} /$ min in cases of cardiogenic shock with maintained blood pressure so as to restore cardiac output (strong agreement).

- It is probably advisable to use milrinone (continuous perfusion of $0.5-0.75 \mu \mathrm{g} / \mathrm{kg} / \mathrm{min}$ ) as an alternative to dobutamine in children with cardiogenic shock, especially in post-cardiac surgery patients and in cases with impaired right ventricle function and/or associated pulmonary arterial hypertension (strong agreement).

- Levosimendan (continuous perfusion of 0.1-0.2 $\mu \mathrm{g} /$ $\mathrm{kg} / \mathrm{min}$ ) may be used as second-line treatment in patients with cardiogenic shock who do not respond to the usual therapy (dobutamine or milrinone with or without diuretics), especially for postoperative management after cardiac surgery (strong agreement).

Dobutamine is still the gold standard inotrope for the dynamic assessment of the cardiovascular system and is used as the reference inotrope in comparative studies [28]. After cardiac surgery, low doses $(2.5 \mu \mathrm{g} / \mathrm{kg} / \mathrm{min})$ of dobutamine increase the cardiac index and high doses $(20 \mu \mathrm{g} / \mathrm{kg} / \mathrm{min})$ improve the cardiac index in patients with Alagille syndrome [29, 30]. Its hemodynamic effects are identical to those of dopamine but without leading to increased pulmonary vascular resistance [31]. A review has been recently published regarding pharmacokinetics and pharmacodynamics of dobutamine in neonates, including studies in children [32].

When used to treat septic shock with normo/hypokinesia and compared with a placebo, milrinone (loading dose of $50 \mu \mathrm{g} / \mathrm{kg}$, followed by continuous perfusion of $0.5 \mu \mathrm{g} /$ $\mathrm{kg} / \mathrm{min}$ for $2 \mathrm{~h}$ ) increases the cardiac index, stroke volume index, and oxygen delivery $\left(\mathrm{DO}_{2}\right)$ and reduces systemic and pulmonary vascular resistance and the mean pulmonary arterial pressure $30 \mathrm{~min}, 1 \mathrm{~h}$, and $2 \mathrm{~h}$ after a loading dose of $50 \mu \mathrm{g} / \mathrm{kg}$ [33]. Bailey et al. [34] demonstrated that the standardized loading dose of $50 \mu \mathrm{g} / \mathrm{kg}$ over $5 \mathrm{~min}$ was associated with a $12 \%$ decrease of the mean arterial pressure and an $18 \%$ increase of the cardiac index. Some authors have compared a placebo group with both a "low dose" group $(25 \mu \mathrm{g} / \mathrm{kg}$ over $60 \mathrm{~min}$, followed by continuous perfusion of $0.25 \mu \mathrm{g} / \mathrm{kg} / \mathrm{min}$ for $35 \mathrm{~h}$ ) and a "high dose" group $(75 \mu \mathrm{g} / \mathrm{kg}$ over $60 \mathrm{~min}$, followed by continuous perfusion of $0.75 \mu \mathrm{g} / \mathrm{kg} / \mathrm{min}$ for $35 \mathrm{~h}$ ). The high dose of milrinone reduced the risk of low cardiac output by $55 \%$ at $36 \mathrm{~h}(p=0.023)$ and by $48 \%$ at 30 days $(p=0.049)$ [35]. In practice, the loading dose of milrinone has been abandoned due to the risk of vasoplegia. In a series of 40 post-cardiac surgery children, Lechner et al. [36] found that levosimendan $(0.1 \mu \mathrm{g} / \mathrm{kg} / \mathrm{min})$ had a greater effect than milrinone $(0.5 \mu \mathrm{g} / \mathrm{kg} / \mathrm{min})$ on cardiac index and cardiac output. In 15 children with acute heart failure, levosimendan was associated with an improved left ventricular end systolic fraction and allowed the patients to be given lower doses of catecholamines [37]. As for milrinone, in practice, the loading dose of levosimendan has been abandoned due to the risk of vasoplegia.

\section{Usefulness of vasopressors in the management of cardiogenic shock}

- If vasopressors are combined with inotropes to achieve adequate perfusion pressure, it is probably advisable to use noradrenaline as first-line treatment, especially in patients with low cardiac output, reduced vascular resistance, and persistent hypotension (strong agreement).

- Noradrenaline should be replaced by adrenaline in patients with inotrope-resistant cardiogenic shock (strong agreement).

- It is probably not advisable to use dopamine to treat cardiogenic shock in children (strong agreement).

- It is probably advisable to use terlipressin/arginine vasopressin as last-resort treatment in children with vasopressor-resistant cardiogenic shock (common vasopressors such as noradrenaline and adrenaline) (strong agreement). 
In 2011, Levy et al. [38] demonstrated the advantage of combining the use of norepinephrine, dobutamine, and dopamine in adult patients with cardiogenic shock. Two forms of the arginine vasopressin (AVP) hormone are used in clinical practice: exogenous AVP and terlipressin, a synthetic analog with a longer half-life $(6 \mathrm{~h}$ vs. $24 \mathrm{~min}$ for AVP). There are thirty-five reports in the literature on its clinical use in neonates, children, and adolescents; seven of the studies investigated its use in patients with low cardiac output and/or severe vasodilation after cardiac surgery, and four for cardiopulmonary resuscitation [39]. In the context of pediatric cardiac surgery (neonates and children), it seems more likely that the positive effects of exogenous AVP [40] and terlipressin [41] are due to restored vascular tone than to improved left ventricular function [42, 43]. However, analysis of the pediatric cases recorded in the North American registry of cardiopulmonary resuscitated patients suggested that AVP had a deleterious effect on the possibility of return of spontaneous circulation [44].

\section{Usefulness of vasodilators in the management of cardiogenic} shock

- It is probably not advisable to use nitrated derivatives to treat cardiogenic shock in children (strong agreement).

Several series of cases evidenced a positive effect when nitroprussiate was used to treat patients with low cardiac output after cardiac surgery $[45,46]$. Similar findings were reported for acute cardiac failure [47].

\section{Usefulness of antiarrhythmic agents in the management of cardiogenic shock}

- Beta-blockers should not be used to treat cardiogenic shock in children (strong agreement).

Meta-analysis of three studies assessing the effect of beta-blockers in children with chronic congestive heart failure produced conflicting results. The study with the largest population (161 children) demonstrated the nonsuperiority of carvedilol over placebo using a composite score for heart failure [48]. Another study suggested the superiority of procainamide over amiodarone for emergency treatment of recurring supraventricular tachycardia [49].

\section{Other therapeutic principles}

Usefulness of sedation/analgesia in cardiogenic shock

- No expert recommendations

\author{
Usefulness of anticoagulants/anti-aggregation agents \\ in cardiogenic shock \\ - No expert recommendations
}

Usefulness of therapeutic hypothermia in cardiogenic shock

- No expert recommendations

\section{Usefulness of continuous renal replacement therapy \\ in cardiogenic shock}

- No expert recommendations

\section{Usefulness of transfusion in cardiogenic shock \\ - No expert recommendations}

\section{Usefulness of immunoglobulins in the management of cardiogenic shock in children with myocarditis}

- In cases of acute myocarditis with cardiogenic shock, it is probably not advisable to use immunoglobulins (strong agreement).

According to a recent report, fulminant myocarditis results in cardiogenic shock in $28 \%$ of cases [9]. No prospective randomized pediatric studies have assessed the use of immunoglobulins to treat acute myocarditis [50]. The largest multicenter trial, a retrospective study on 100 patients, showed that treatment with immunoglobulins did not improve pediatric patient survival, whatever the severity score [51].

\section{Usefulness of immunosuppressive therapy in the management of cardiogenic shock in children with myocarditis}

- In cases of acute myocarditis with cardiogenic shock, it is probably not advisable to use immunosuppressant drugs (strong agreement).

Meta-analysis of 9 studies (a total of 139 children treated with different immunosuppressant drugs) showed no benefit of immunosuppressive therapy in patients with myocarditis [52]. Two randomized prospective studies showed a favorable effect on restoring left ventricular function in children with chronic heart failure following myocarditis [53, 54], but combined the use of variable doses of corticoids, azathioprine, and ciclosporine.

\section{Comparison of the usefulness of noninvasive ventilation} versus invasive ventilation in the management of cardiogenic shock

- Noninvasive ventilation should not be preferred over invasive ventilation in children with cardiogenic shock (strong agreement).

No studies have compared the use of noninvasive ventilation and invasive ventilation in children with acute heart failure. Noninvasive ventilation (continuous positive airway pressure or Bi-level airway pressure) is effective in 66-80\% of cases when used in pediatric post-cardiac surgery patients, notably in the presence of atelectasis or pulmonary edema $[55,56]$. A team from Turkey reported the use of a noninvasive ventilation with a helmet in 3 children 
aged 18 months, 5 years, and 7 years with cardiogenic pulmonary edema following scorpion envenomation [57].

\section{Usefulness of cardiac resynchronization therapy in the management of cardiogenic shock}

- Cardiac resynchronization therapy should not be used in children with cardiogenic shock (low overall level of evidence, strong agreement).

No studies have investigated the usefulness of cardiac resynchronization therapy in pediatric patients with cardiogenic shock. Nevertheless, few studies have been carried out on children with severe acute heart failure following cardiac surgery. These studies are based on small numbers of hemodynamically stable patients and did not include control groups [58-62].

\section{Field of application 3: monitoring hemodynamic and biological variables}

\section{Usefulness of clinical monitoring in the management}

\section{of cardiogenic shock}

- Patients with cardiogenic shock should be clinically examined several times a day to evaluate the effectiveness or in-effectiveness of treatment (pulse volume, peripheral perfusion, heart rate, preload, hepatomegaly, auscultation crackles, distended jugular veins, edema syndrome) (strong agreement).

- Monitoring data for children with cardiogenic shock should also include hourly diuresis measurements and the input/output balance (strong agreement).

On auscultation of children with cardiogenic shock, tachycardia, gallop rhythm, heart murmur, and signs of lung congestion can be detected. Peripheral pulses are often weakest. Hepatomegaly, distended jugular veins, and peripheral edema are nearly always detected in children with cardiogenic shock [63]. In infants, supraventricular tachycardia should be suspected if tachycardia with a heart rate $>220$ bpm occurs suddenly.

\section{Usefulness of chest X-rays in the management of cardiogenic shock}

- The initial examination of cardiogenic shock patients should include a chest X-ray (low level of evidence, strong agreement).

Chest X-ray generally shows cardiomegaly (antero-posterior projection, end-inspiration; cardiothoracic ratio $>0.6$ in neonates, $>0.55$ in infants, and $>0.5$ in children). Chest X-ray is used to assess the state of the parenchyma and lung vessels. They can evidence perihilar fluffy opacities with butterfly/bat wing patterns (pulmonary edema of cardiogenic origin), the water bottle sign (pericardial effusion), or a boot-shaped heart (right ventricular dilatation) [63-66].

\section{Usefulness of monitoring laboratory values in the management of cardiogenic shock}

- Arterial pH and blood lactate levels should be determined repeated to assess the course of shock and evaluate the efficacy of therapeutic measures (strong agreement).

- The levels of the following variables should be quantified at regular intervals to assess organ dysfunction in patients with cardiogenic shock: plasma ions, blood urea and creatinine, blood glucose, transaminases (strong agreement).

- Repeated determination of CPK-MB levels

- It is probably not advisable to determine blood CPK-MB levels in patients with cardiogenic shock (strong agreement).

- Repeated determination of NT-proBNP levels

- BNP/NT-proBNP levels should be quantified at regular intervals in patients with cardiogenic shock to assess the severity of heart disease (strong agreement).

- Repeated determination of troponin levels

- Troponin levels should be quantified at regular intervals in patients with cardiogenic shock to assess the severity of myocardial involvement as well as the response to treatment (strong agreement).

Blood lactate level, used as a predictor of mortality, is one of the therapy goals for sepsis management in both children and adults [67]; depending on the studies, the goal value ranges from 2 to $3 \mathrm{mmol} / \mathrm{L}[68,69]$. Increased lactate levels can be due to the use of inotropes (adrenaline, dobutamine), hyperventilation, and impaired mitochondrial function without circulatory collapse, and certain volume expansion fluids [70]. In patients with cardiogenic shock, the increase in CPK-MB is not correlated with the severity of myocardial involvement [71]. The different troponin isoforms are more specific and sensitive markers of acute myocardial involvement than CPK-MB [71]; even though to date and unlike what is observed in adults, the prognostic value of troponin is not clearly established in pediatric patients with cardiogenic shock [72]. In neonates and children, the normal values of troponin and CPK-MB are $0.2-0.4$ and $0.6 \mu \mathrm{g} / \mathrm{L}$, respectively. The prognostic value of BNP in children with cardiogenic shock has not been demonstrated formally even though its determination is still used widely to assess the severity of cardiac involvement, particularly in patients with preexisting cardiomyopathy [73]. A recent report based on 181 pediatric cases demonstrated the relevance of BNP when assessing the severity of congestive heart failure [74]. Gessler et al. [75] demonstrated that the increase in preoperative NT-proBNP levels was associated with the quantity of inotropes used during 
the postoperative period in 40 children who underwent cardiac surgery. However, these results have yet to be confirmed by other teams [76]. At the beginning of the twenty-first century, the use of NT-proBNP levels as a marker discriminating between the pulmonary and cardiac causes of dyspnea was assessed in children [77]. In adults with cardiogenic shock, BNP levels appear to correlate well with mortality and morbidity rates [78].

\section{Usefulness of hemodynamic monitoring in cardiogenic shock}

\section{Usefulness of noninvasive hemodynamic monitoring}

in cardiogenic shock

\section{Oxygen saturation: $\mathrm{SpO} 2$}

- $\mathrm{SpO} 2$ values should be monitored continuously in children with cardiogenic shock (strong agreement).

- $\mathrm{SpO} 2$ is an essential indicator for monitoring a patient with decompensated circulatory failure. Its value should be evaluated together with clinical assessment and arterial blood gas values $(\mathrm{SaO} 2)[11$, 79].

\section{Electrocardiogram: ECG}

- Patients with cardiogenic shock should undergo ECG examination in order to guide diagnosis (pericarditis, myocarditis, coronary ischemia, pulmonary embolization) and/or diagnose possible rhythm disorders that are causing cardiogenic shock (strong agreement).

- If in doubt, a pediatric cardiology team should be contacted to analyze the ECG (strong agreement).

- An ECG is essential and should be repeated at regular intervals during the course of cardiogenic shock in children [63]. It may show abnormalities related to underlying heart disease [12], rhythm disorders due to cardiomyopathy [80, 81], supraventricular tachycardia or specific signs of an acute condition such as pericarditis (microvoltage), viral myocarditis (repolarization issues, ST-segment elevation or depression, related ventricular rhythm disorders), myocardial infarction in Kawasaki disease (Q wave, ST-segment depression), or drug intoxication [65].

\section{Noninvasive arterial pressure}

- We strongly recommend use of an arterial catheter to measure the arterial blood pressure in patients with decompensated circulatory failure as seen in cardiogenic shock (strong agreement).

- Only invasive techniques provide reliable measurements in such patients with circulatory failure, especially when decompensated [82]. Noninvasive arterial blood pressure measurements can be complicated to obtain in neonates [83] and require special equip- ment. The authors of one study [84] advise using an arm cuff of width equal to $40 \%$ of the upper arm circumference. However, this technique overestimates the diastolic blood pressure. If blood pressure is difficult to measure noninvasively in a child with impaired consciousness and an irregular $\mathrm{O}_{2}$ saturation curve, then hemodynamic failure can be suspected.

\section{Usefulness of TTE monitoring in cardiogenic shock}

- We strongly recommend that all PICU have a 24/7 transthoracic echocardiogram (TTE) service (strong agreement).

- In patients with acute circulatory failure as seen in cardiogenic shock, TTE should be used to assess cardiac function (strong agreement).

- We strongly advise contacting a pediatric cardiology team (by phone, bedside visit, etc.) if a child with cardiogenic shock is admitted to PICU (strong agreement).

- In cardiogenic shock patients, at least the following items should be assessed using TTE: systolic and diastolic function of both ventricles, pulmonary pressures and coronary visualization, confirmation of normal cardiac structure (strong agreement).

- We strongly advise use of TTE when performing pericardial puncture in patients with tamponade (ultrasound-guided drainage) (strong agreement).

- TTE should be performed if a patient suffers from cardiogenic shock following cardiac surgery (strong agreement).

- We strongly recommend that specific certification courses in TTE be implemented at the national level for neonatal and pediatric intensive care practitioners (strong agreement).

TTE is recommended in the management of septic shock [85]. Few studies focus on the diagnostic and prognostic value of TTE in pediatric cases of cardiogenic shock [86]. It is the ideal point-of-care technique [87]. TTE enables even those with minimal training to rapidly detect pericardial effusion or impaired left ventricular function $[88,89]$. It can also be used to assess the efficacy of therapeutic measures and any related complications. In scorpion envenomation patients with authentic cardiogenic shock, it was shown that early observation of proper left ventricular function using TTE had a very good positive predictive value for recovery without heart failure [86]. TTE should be used at the earliest stage when possible in order to detect subclinical abnormalities. To monitor the cardiotoxicity of cytotoxic drugs, some authors recommend routine TTE assessment before administering the drugs and then at 1 week, 6 months, 
and 1 year [90]. It is essential that residents and senior residents receive training on functional TTE in intensive care [91].

\section{Usefulness of near-infrared spectroscopy (NIRS) monitoring in cardiogenic shock}

- Cerebral, mesenteric, or renal NIRS can be used to monitor organ perfusion in patients with cardiogenic shock (strong agreement).

NIRS measures oxygenation at the microcirculatory level in vessels of diameter $<1 \mathrm{~mm}$ [92]. Its value varies from organ to organ and depends on each organ's metabolism. This technique has mostly been used in unstable children undergoing cardiac surgery (intra- and postoperatively). During extracorporeal circulation, at the time of the aortic cross-clamping, cerebral and somatic NIRS values can be informative, whereas $\mathrm{SpO} 2$ values are not available [93]. NIRS values are correlated with continuous venous $\mathrm{O}_{2}$ saturation $\left(\mathrm{S}_{\mathrm{cv}} \mathrm{O}_{2}\right)$ in the superior vena cava without, however, replacing it [94]. Chakravarti et al. [95] showed that in post-cardiac surgery patients a cerebral and/or renal NIRS value of $<65 \%$ was predictive of a lactate level of over $3 \mathrm{mmol} / \mathrm{L}$ which in turn reflects tissue hypoperfusion related to reduced cardiac output. Other authors have shown that in neonates and infants with congenital heart disease requiring surgery or catheterization, the splanchnic NIRS value was correlated with $\mathrm{SvO} 2$, lactate levels, and gastric $\mathrm{pH}$ [96]. Recent case reports have demonstrated the usefulness of cerebral and renal NIRS as a guide for resuscitation of children in cardiac arrest [97, 98].

\section{Usefulness of invasive hemodynamic monitoring}

Usefulness of arterial oxygen pressure $\left(\mathrm{P}_{\mathrm{a}} \mathrm{O}_{2}\right) /$ central venous pressure (CVP) monitoring in cardiogenic shock

- It is advised to monitor $\mathrm{S}_{\mathrm{a}} \mathrm{O} 2$ and $\mathrm{P}_{\mathrm{a}} \mathrm{O}_{2}$ values in patients with severe respiratory diseases, some of which can be associated with or cause severe heart failure (strong agreement).

- It is advised to monitor $\mathrm{P}_{\mathrm{a}} \mathrm{O}_{2}$ by measuring arterial blood gas in patients with decompensated circulatory failure (strong agreement).

- Vascular access should be obtained in patient with cardiogenic shock by inserting a central venous catheter, preferably in the superior vena cava (strong agreement).

- CVP values (and moreover CVP kinetics in a given patient) can provide information on the preload reserve in children with cardiogenic shock (strong agreement).
If possible CVP measurements should be performed at the end of expiration, and without mechanical ventilation running (apnea). According to some authors, if the same values are obtained with and without mechanical ventilation, subsequent measurements can be performed with ventilation [70,99]. Usual CVP values range from 2 to $8 \mathrm{~cm} \mathrm{H}_{2} \mathrm{O}(1-6 \mathrm{~mm} \mathrm{Hg})$. Return to normal CVP values is one of the goals of sepsis management in children [67]. The CVP value provides information on right ventricular preload; however, the relevance of this measurement in unstable, intubated, and ventilated children is limited.

\section{Usefulness of central venous oxygen saturation $\left(\mathrm{S}_{\mathrm{cv}} \mathrm{O}_{2}\right)$ monitoring in cardiogenic shock}

- We strongly recommend that $\mathrm{S}_{\mathrm{cv}} \mathrm{O}_{2}$ be measured continuously or discontinuously in the superior vena cava during cardiogenic shock (strong agreement).

- We strongly recommend aiming to reach an upper target value of $70 \%$ (which reflects normal arterial oxygen transport). A value $<65-70 \%$ with persistent clinical and laboratory signs of shock can reflect inadequate arterial oxygen transport and should spur efforts to improve oxygen transport by increasing cardiac output and/or transfusion of packed red blood cells (strong agreement).

- It is advised to monitor $\mathrm{S}_{\mathrm{a}} \mathrm{O} 2$ and $\mathrm{P}_{\mathrm{a}} \mathrm{O}_{2}$ values in patients with severe respiratory diseases, some of which can be associated with or can cause severe heart failure (strong agreement).

Continuous central venous oxygen saturation $\left(\mathrm{S}_{\mathrm{cv}} \mathrm{O}_{2}\right)$, a variable used to assess microcirculatory and macrocirculatory hemodynamics, provides information on the balance between demand and supply of $\mathrm{O}_{2}$ to the tissues. It is measured in the superior vena cava [100] and is one of the goals set by the Surviving Sepsis Campaign (>70 \%) [67]. The reliability of $\mathrm{S}_{\mathrm{vc}} \mathrm{O}_{2}$ measurements compared with $\mathrm{S}_{\mathrm{V}} \mathrm{O}_{2}$ values obtained using pulmonary artery catheters is a subject of discussion. Grissom et al. [101] showed that if the $\mathrm{S}_{\mathrm{cv}} \mathrm{O}_{2}$ value measured in the superior vena cava $\geq 70 \%$ in adults with acute lung injury, then it was unlikely that the mixed venous oxygen saturation $\left(\mathrm{S}_{\mathrm{v}} \mathrm{O}_{2}\right)$ value measured by pulmonary artery catheter would be $<60 \%$. On the other hand, a $\mathrm{S}_{\mathrm{cv}} \mathrm{O}_{2}$ value $<70 \%$ did not reliably predict a $\mathrm{S}_{\mathrm{V}} \mathrm{O}_{2}$ value $<60 \%$ (positive predictive value of $31 \%$ ). $\mathrm{S}_{\mathrm{cv}} \mathrm{O}_{2}$ measurements overestimate the $\mathrm{S}_{\mathrm{V}} \mathrm{O}_{2}$ by approximately 3-8\%. The kinetics of these 2 variables are fairly well, although not perfectly, correlated [102]. Recently, De Oliveira et al. [22] demonstrated that a significant decrease in mortality could be achieved if a target value of $\mathrm{S}_{\mathrm{cv}} \mathrm{O}_{2}>70 \%$ was implemented in 
sepsis management in children. $\mathrm{S}_{\text {cv }} \mathrm{O}_{2}$ can be considered as an interesting marker while not perfect of the balance between oxygen transport and tissue oxygen consumption. In case of shock, and particularly in case of septic shock, changes and heterogeneity of regional and tissue flows should give cautious to an analysis of $\mathrm{S}_{\mathrm{cv}} \mathrm{O}_{2}$ value alone.

\section{Usefulness of invasive arterial pressure monitoring in cardiogenic shock}

- We strongly advise use of an arterial catheter to measure arterial blood pressure in patients with decompensated circulatory failure as seen in cardiogenic shock (strong agreement).

Radial access (palmar arch) should be preferred in children even if the validity of the Allen test is not unequivocal. Arterial catheters allow unstable children to be monitored, especially if receiving inotropes or vasopressors [70]. Intraoperative and postoperative monitoring during cardiac surgery or other prolonged or potentially hemorrhagic surgical procedures requires hemodynamic measurements with invasive arterial pressure readings.

\section{Usefulness of pulmonary arterial pressure $/ \mathrm{SvO}_{2}$ monitoring in cardiogenic shock}

- In patients with cardiogenic shock who do not respond to first-line treatment, pulmonary artery catheter placement, if necessary, should be performed by a team familiar with this technique (strong agreement).

- Routine pulmonary artery catheter placement is not recommended in children with cardiogenic shock (strong agreement).

Pulmonary artery catheter is only rarely used in children even if their placement in adults is the standard technique for measuring cardiac output [103]. Pulmonary artery catheter measures the heart chamber pressures and cardiac output using thermodilution. Pulmonary artery catheter also provides continuous information about the mixed venous oxygen saturation $\left(\mathrm{S}_{\mathrm{v}} \mathrm{O}_{2}\right)$ and right ventricular ejection fraction and enables placement of an electrosystolic probe in the right ventricle. Finally, pulmonary artery catheter can be used to perfuse the patient and collect blood samples from each heart chamber. Additional file 1: Table S1 summarizes the normal values of variables measured or calculated using a pulmonary artery catheter [104]. The variation in the values measured using the pulmonary artery catheter provides information on the patient's hemodynamic and circulatory status. Right atrium pressure increases with hypervolemia, right ventricular dysfunction, or increased juxtacardiac pressure (pericarditis, pneumothorax, and elevated positive expiratory pressure). Pulmonary artery pressure increases with pulmonary arterial hypertension, left ventricular dysfunction, pulmonary embolization, intracardiac shunts (heart disease or lung disease), and positive expiratory pressure and, in contrast, decreases with hypovolemia, shock, right ventricular impairment, and lung failure. Pulmonary arterial wedge pressure increases with hypervolemia, left ventricular impairment, increased left ventricular afterload, and increased juxtacardiac pressure and decreases with hypovolemic, distributive, and septic shock.

\section{Usefulness of thermodilution cardiac output monitoring in cardiogenic shock}

- Cardiac output determination by thermodilution/ pulse contour analysis using a $\mathrm{PICCO}^{\circledR}$-type system may be considered in patients with cardiogenic shock refractory to first-line treatment (strong agreement).

Cardiac output determination by thermodilution has been developed in adults using a pulmonary artery catheter (Pulmonary Arterial ThermoDilution). Less invasive methods have also been developed to determine the cardiac output by thermodilution using a central venous catheter and an arterial catheter (TransPulmonary ThermoDilution, TPTD). Such methods have been validated in animals [105] and children $[106,107]$, in particular by comparison with Pulmonary Arterial ThermoDilution values or using the Fick equation. Two methods exist: the $\mathrm{PICCO}^{\mathrm{TM}}$ system (Pulsion Medical Systems, Munich, Germany) which uses thermodilution + waveform and the $\mathrm{LiDCO}^{\mathrm{TM}}$ system (LiDCO Ltd, Cambridge, UK) which uses dilution + PulseCO. The PICCO ${ }^{\mathrm{TM}}$ system uses a solution of cold saline or dextrose (thermodilution) at $13{ }^{\circ} \mathrm{C}$ less than the body temperature (in practice often close to $0{ }^{\circ} \mathrm{C}$ ) that is injected via the central catheter (subclavian or internal jugular) and detected by a thermistor placed in an arterial catheter in the femoral area. This method is easy to set up but requires frequent calibration. The $\mathrm{LiDCO}^{\mathrm{TM}}$ system uses a solution of lithium chloride (lithium dilution) which has the advantage that it can be injected via a peripheral venous catheter. The solution is then detected by a sensor on a catheter placed in the radial artery [108]. Cardiac output determinations using the $\mathrm{LiDCO}^{\mathrm{TM}}$ system are very well correlated with Pulmonary Arterial ThermoDilution measurements [108] as well as with values obtained using the $\mathrm{PICCO}^{\mathrm{TM}}$ system [103]. However, the use of LIDCO has a very limited experience in childhood and has not been validated yet in such circumstances. 


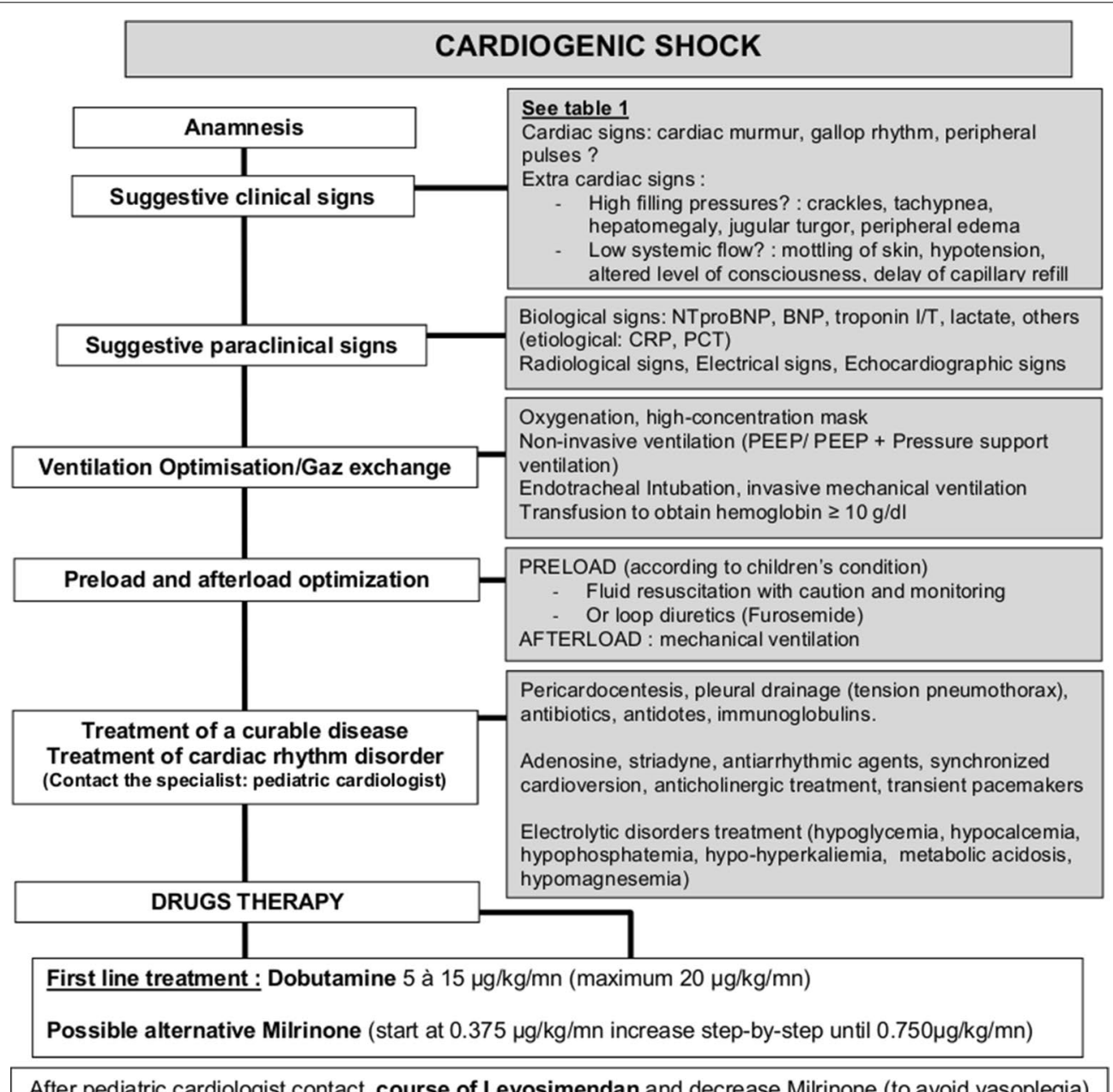

After pediatric cardiologist contact, course of Levosimendan and decrease Milrinone (to avoid vasoplegia)

Second line treatment :
Noradrénaline (start at $0.01 \mu \mathrm{g} / \mathrm{kg} / \mathrm{mn}$ ) should be started if SVR are low (typically Sepsis-induced
myocardial failure)
If persistent hypotension despite Dobutamine, replace the initial treatment by the association Milrinone-
Epinephrine (+/- Levosimendan)
If persistent hypotension despite Milrinone (+/- Levosimendan), epinephrine can be associated (start at
$0.05 \mu \mathrm{g} / \mathrm{kg} / \mathrm{mn})$

Third line treatment:

Terlipressin/vasopressin

Extra-Corporeal Membrane Oxygenation

\section{CLINICAL AND PARACLINICAL MULTIMODAL MONITORING}

Fig. 2 Decision tree for the management of children with a cardiogenic shock. (PEEP positive end expiratory pressure, SVR systemic vascular resistance)

Field of application 4: circulatory support (indications, techniques, organization, and transfer criteria)

First-line circulatory support in children with cardiogenic shock is venoarterial extracorporeal membrane oxygenation (ECMO). In 1992, del Nido et al. [109] suggested using ECMO for cardiac arrest (extracorporeal cardiopulmonary resuscitation) at an early stage during the low cardiac output phase to reduce neurological complications. ECMO maintains tissue oxygenation pending recovery of heart function. Frequent use of ECMO following cardiac surgery for congenital or acquired 
cardiomyopathy in pediatric patients has led care facilities to purchase the specialized equipment needed for this technique.

\section{Usefulness of arteriovenous extracorporeal membrane oxygenation for the management of cardiogenic shock in children}

- We strongly recommend using ECMO in patients with cardiogenic shock refractory to conventional therapy (strong agreement).

No prospective randomized studies have been carried out on pediatric populations to compare morbidity and mortality of patients with cardiogenic shock or cardiac arrest with or without circulatory support by ECMO. Analysis of the Extracorporeal Life Support Organization (ELSO) registry (https://www.elso.org/), which in July 2013 included information on 55,668 patients, shows that the use of ECMO has decreased since 1992 in neonates and pediatric patients for respiratory indications (since when inhaled nitric oxide has been used in clinical practice), but has increased continuously over the same period for cardiac indications. Two main indications are observed: severe heart failure or cardiogenic shock and cardiac arrest. Delayed use of ECMO in patients with cardiogenic shock increases the risk of cardiac arrest. Numerous retrospective studies [110-120], as well as data from the ELSO registry (https://www.elso.org/), show that when ECMO is used the mean patient survival is $>40 \%$ for cardiogenic shock and $>35 \%$ for cardiac arrest. The prognosis for myocarditis is very good if ECMO is started prior to cardiac arrest [121-124]. The complications associated with ECMO are mostly neurological: electrical and clinical seizure, cerebral infarction and bleeding, brain death. Depending on patient populations, Brown et al. [121] reported persisting low-tomoderate disabilities in $12-50 \%$ of patients treated with ECMO. In 16 survivors of a series of 39 children treated with ECMO, Lequier et al. [125] reported a mean score of $73 \pm 16$ on the Bayley scale at 2 years of age. Eight patients showed moderate mental retardation.

\section{Extracorporeal membrane oxygenation in patients with cardiac arrest}

- We strongly recommend using ECMO in patients with cardiac arrest within $\geq 15 \mathrm{~min}$ and $<60 \mathrm{~min}$ (strong agreement).

According to International Liaison Committee on Resuscitation, use of ECMO should be considered in children with cardiac arrest refractory to conventional cardiopulmonary resuscitation, if cardiac arrest occurred in a highly monitored setting and the necessary support equipment and expertise are available to implement the technique rapidly [126]. In a series of 682 patients with a median age of 3 months (ELSO registry) treated with extracorporeal cardiopulmonary resuscitation [127], the survival rate after discharge was $38 \%$. This study suggests that a $\mathrm{pH}<6.9$ prior to ECMO is significantly associated with death within $72 \mathrm{~h}$ or a poor neurological prognosis. The meta-analysis performed by Tajik and Cardarelli [128] of 37 studies (288 patients) including case reports and observational pediatric studies on patients with cardiac arrest treated with extracorporeal cardiopulmonary resuscitation, showed that survival rate was very variable: It ranged from 0 to $100 \%$ in small centers that had low numbers of patients and from 6 to $79 \%$ for the larger cohorts. Matos et al. [116] demonstrated that morbidity and mortality increase if cardiopulmonary resuscitation lasts $>15 \mathrm{~min}$ and that conventional resuscitation reaches its limits with a likelihood of survival of $41 \%$ for cardiopulmonary resuscitation lasting 1-15 min, but only $12 \%$ if cardiopulmonary resuscitation lasts $>35 \mathrm{~min}$. The neurological prognosis of survivors is good and reaches $70 \%$ when cardiopulmonary resuscitation lasts $<15 \mathrm{~min}$ and $60 \%$ if CPR lasts $<35 \mathrm{~min}$. The survival of children undergoing cardiac surgery is $38.5 \%$ if cardiopulmonary resuscitation lasts $>35 \mathrm{~min}$ and ECMO is used, but drops to $16.7 \%$ if ECMO is not used $(p<0.0001)$. Turek et al. [120] reported that if ECMO was implemented within $40 \mathrm{~min}$ using a previously prepared circuit, neurological complications were decreased by $52 \%(p<0.04)$ compared with the conventional method ( $>40 \mathrm{~min})$. However, no decrease in the mortality rate was observed. In a series of 42 children treated with extracorporeal cardiopulmonary resuscitation, Delmo-Walter et al. [112] showed a difference of mortality depending on the duration of cardiopulmonary resuscitation prior to implementation of ECMO: $30 \pm 1.3$ min vs. $46 \pm 4.2 \mathrm{~min}(p=0.003)$. The faster the limits of cardiopulmonary resuscitation are recognized, the earlier ECMO should be initiated, thereby limiting mortality and organ lesions [129].

\section{Usefulness of mechanical ventricular assist devices in the management of cardiogenic shock in children}

- We recommend that the use of ventricular assist devices in pediatric patients with cardiogenic shock refractory to conventional therapy be discussed with cardiologists (strong agreement).

No prospective randomized studies have been performed to compare the morbidity and mortality of children with cardiogenic shock treated with or without a ventricular assist device. In a single-center retrospective study including 16 children with fulminant myocarditis, Wilmot et al. [124] reported a survival rate of $75 \%$ at discharge whatever the support method used (ventricular assist device or ECMO). 


\section{Usefulness of extracorporeal membrane oxygenation implementation criteria for children with cardiogenic shock}

- To lower the risks of mortality and neurological morbidity, we strongly recommend implementing ECMO when $\mathrm{pH} \geq 7.2$ and lactate $<9 \mathrm{mmol} / \mathrm{L}$ and using low-to-moderate inotrope support (strong agreement).

- The decision to implement ECMO in children with cardiogenic shock is based on clinical, laboratory, and prognostic criteria, the relevance of which must be considered jointly by pediatric cardiologists and intensive care physicians (strong agreement).

No prospective randomized studies have been performed to define specific criteria for ECMO implementation in children with cardiogenic shock. Based on data from the ELSO registry in 2005, Thiagarajan et al. [127] reported a mean pre-ECMO arterial $\mathrm{pH}$ of 7.26 (7.067.38) for survivors and 7.17 (6.9-7.36) for non-survivors $(p=0.001)$. Multivariate analysis demonstrated that the mean pre-ECMO pH was $<6.9$ in the group of children with the highest mortality. For the same patient population, Barrett et al. [130] demonstrated that neurological prognosis was poorest for children with a $\mathrm{pH}<6.865$. Two studies by Huang et al. [114, 131], which included 27 and 54 cases of extracorporeal cardiopulmonary resuscitation and 41 and $46 \%$ of survivors, respectively, revealed that pre-ECMO lactate levels were statistically higher in non-survivors than in survivors [for the first study $14(10.2-19.6)$ vs. 8.5 (4.4-12.6) $\mathrm{mmol} / \mathrm{L}, p<0.01$ and for the second study $13.4 \pm 6.4 \mathrm{vs} .8 .8 \pm 5.1 \mathrm{mmol} / \mathrm{L}$, $p<0.01]$. In 218 post-cardiac surgery pediatric patients, Trittenwein et al. [132] reported that the predicted postoperative mortality was $80 \%$ if the patient showed arterial lactate levels $>7.7 \mathrm{mmol} / \mathrm{L}$ with $\mathrm{S}_{\mathrm{cv}} \mathrm{O}_{2}<60 \%$, or if arterial lactate levels $>18 \mathrm{mmol} / \mathrm{L}$ and $\mathrm{S}_{\mathrm{cv}} \mathrm{O}_{2}>60 \%$ on admission to intensive care $(p<0.05)$. The authors suggest that these levels be used as postoperative criteria for ECMO implementation.

\section{Usefulness of mobile circulatory support units} for implementing extracorporeal membrane oxygenation in patients with cardiogenic shock far from an expert center

- ECMO should be implemented by a team of trained healthcare professionals (strong agreement).

- Patients treated with ECMO should be transferred to an expert center (strong agreement).

No randomized studies have been performed on the use of mobile circulatory support units. Before requesting a mobile circulatory support unit, the child's status (cardiogenic shock/cardiac arrest), on-site therapeutic means and hemodynamic assessment measures, and the response time of the mobile circulatory support unit should be taken into account.

\section{Usefulness of expert centers for managing pediatric patients with cardiogenic shock treated with venoarterial extracorporeal membrane oxygenation}

- Candidate pediatric ECMO reference centers should perform at least 15-20 ECMOs on pediatric patients per year (strong agreement).

No randomized studies have been performed on expert pediatric ECMO centers.

An expert center must have a multidisciplinary technical platform that can ensure complete care of pediatric patients treated with ECMO for both medical and surgical indications. In a study based on 3867 pediatric congenital cardiopathy patients treated with ECMO, Karamlou et al. [133] showed that low in-hospital mortality was associated with centers that managed large numbers of ECMO cases ( $>30 /$ year; $p=0.01$ ), whereas low ECMO activity (<15/year) was a risk factor for in-hospital mortality (OR 1.75; CI $95 \%$ 1.03-2.94; $p=0.03$ ).

\section{Conclusion}

We report here experts' recommendations regarding management of children with cardiogenic shock. We hope this work will help healthcare professionals in their daily practice. We propose in conclusion a decision tree (Fig. 2) for the management of cardiogenic shock in children by referring to recommendations we have published.

\section{Additional file}

Additional file 1: Table S1. Hemodynamic parameters provided by Pulmonary Artery Catheter (RA : right atrium; RAP: right atrium pressure; RV : right ventricle, LV : left ventricle, SVR : systemic vascular resistance, PVR : pulmonary vascular resistance, $\mathrm{CO}$ : cardiac output, $\mathrm{SvO}_{2}$ : venous oxygen saturation, $\mathrm{SaO}_{2}$ : arterial oxygen saturation, $\mathrm{VO}_{2}=\mathrm{O}_{2}$ consumption, $\mathrm{HR}$ : heart rate, $\mathrm{BSA}$ : body surface area, $\mathrm{M}$ : mean, $\mathrm{Hb}$ : oxygen tension in venous blood, $\mathrm{PaO}_{2}$ : oxygen tension in arterial blood, $\mathrm{rSO}_{2}$ : regional tissue oxygenation).

\section{Authors' contributions}

All the authors participated to the rereading and the correction of the paper. $A B, O B, G C, E G, D L$, and PM contributed to review of the literature, recommendations' building, writing of the manuscript. $A B, O B, G C, E G, D L, P M, L D S B$, $F L, V G, S D$, and PD vote for the recommendations (three rounds). All authors read and approved the final manuscript.

\section{Author details}

${ }^{1}$ Unité de Réanimation Pédiatrique et Néonatale, Hôpital des Enfants, $\mathrm{CHU}$ Pellegrin Enfants, Place Amélie Raba Léon, 33000 Bordeaux, France. ${ }^{2}$ Unité de Réanimation Pédiatrique, Faculté de Médecine, Université de Lille Nord de France, Hôpital Jeanne de Flandre CHU de Lille, 54, Avenue Eugène Avinée, 59037 Lille Cedex, France. ${ }^{3}$ Département de Pédiatrie Néonatale et Réanimations, Pôle Hospitalo-Universitaire Femme-Mère-Enfant, Hôpital 
Arnaud-de-Villeneuve, Centre Hospitalier Régional Universitaire de Montpellier, 371, Avenue du Doyen-Gaston-Giraud, 34295 Montpellier Cedex 5, France. ${ }^{4}$ Réanimation et Surveillance Continue Pédiatriques, Pôle de Pédiatrie Médicale, Hôpital Robert-Debré, Assistance Publique-Hôpitaux de Paris, Université Paris Diderot-Paris 7, Sorbonne Paris Cité, 48, Boulevard Sérurier, 75019 Paris, France. ${ }^{5}$ Service de Réanimation, CHU Necker-Enfants-Malades, 149, rue de Sèvres, 75743 Paris Cedex 15, France. ${ }^{6}$ Réanimation Pédiatrique, AP-HP, CHU Kremlin Bicêtre, 78, rue du Général Leclerc, 94270 Le Kremlin Bicêtre, France. ${ }^{7}$ Service de Cardiologie Pédiatrique, CHU de Nantes, 44093 Nantes Cedex, France. ${ }^{8}$ Pôle des Cardiopathies Congénitales, Centre Chirurgical Marie Lannelongue, 133, Avenue de la Résistance, 92350 Le Plessis-Robinson, France. ${ }^{9}$ Service de Cardiologie Pédiatrique et Congénitale, Hôpital Haut-Lévèque, $\mathrm{CHU}$ de Bordeaux, Avenue de Magellan, 33604 Pessac Cedex, France. ${ }^{10}$ Service de Réanimation Polyvalente, Hôpital de La Source, Centre Hospitalier Régional Orléans, 45067 Orléans, France. ${ }^{11}$ Service de Réanimation Médicale, Hôpital Émile-Muller, 68070 Mulhouse, France.

\section{Acknowledgements}

The authors gratefully acknowledge Dr. P Nolent (Bordeaux-PICU) for reviewing the English of the manuscript.

Groupe d'Experts: Astrid Botte (Lille), Gilles Cambonie (Montpellier), Stéphane Dauger (Paris), Laure de Saint Blanquat (Paris), Philippe Durand (Bicêtre), Véronique Gournay (Nantes), Elodie Guillet (Bordeaux), Daniela Laux (Paris), Francis Leclerc (Lille), Philippe Mauriat (Pessac).

Organisateurs: Thierry Boulain (Orléans), Khaldoun Kuteifan (Mulhouse). Membres du groupe organisant les Référentiels SRLF: L. Donetti (Maux), M. Alves (Poissy), T. Boulain (Orléans), O. Brissaud (Bordeaux), V. Das (Montreuil), L. de Saint Blanquat (Paris-Necker), M. Guillot (Strasbourg), K. Kuteifan (Mulhouse), C. Mathien (Mulhouse), V. Peigne (Clamart), F. Plouvier (Agen), D. Schnell (Strasbourg), L. Vong (Melun).

\section{Expert recommendations: introduction and description of the meth-} odology: The present recommendations, which build on the risk management compendium in cardiology and contribute to the quality improvement program implemented by our approved bodies, are the product of work carried out by a group of experts convened by the Société de Réanimation de Langue Française (SRLF; French Intensive Care Society) and the Groupe Francophone de Réanimation et Urgences Pédiatriques (GFRUP; French Group for Pediatric Intensive Care and Emergencies). Four pediatric experts provided clinical justifications for each of the four fields of application defined by the organization committee. Because the fields of application differ greatly in adults, we chose to formulate recommendations for pediatric patients. For the most part, our recommendations arise from prospective and retrospective observational studies and international consensus. All proposed recommendations were reviewed and discussed individually, each expert being asked to justify the substance and format of his/her proposals, and potentially amend them to take into account comments from peers. Proposals were then rated by the four designated experts and seven associate pediatric experts, all qualified in the specific field. The aim of this review process was not necessarily to reach a single, convergent opinion for each proposal, but to delineate clearly areas of agreement on which the recommendations are based as well as points of contention or indecision that require further investigation. Each expert rated each recommendation using the RAND/UCLA appropriateness method with three rating rounds after eliminating outliers (experts with deviating opinions). Each proposal was rated using a numerical scale ranging from 1 to 9 ( 1 being "disagree entirely," total lack of evidence," or "strictly contraindicated" and 9 being "agree entirely," "formal evidence," or "formally indicated"). Three rating zones were then defined depending on the value of the median: the "disagreement" zone (1-3); the "indecision" zone (4-6); and the "agreement" zone (7-9). The agreement, disagreement, or indecision was said to be "strong" if the median interval was included within one of the three zones (1-3), (4-6), or (7-9). The agreement, disagreement, or indecision was said to be "weak" if the median interval impinged on the boundary of another zone (e.g., [1-4] or [6-8]). The methodology used to formulate these recommendations was based on the GRADE system (http://www.gradeworkinggroup.org//links.htm). The originality of the GRADE approach is notably due to the following aspects: A level of evidence is not assigned to a study solely on the basis of study type (e.g., randomized trial or not); the risk-benefit ratio is taken into account fully; finally, when formulating recommendations, the phrases "should be/should not be (it is/is not advisable to)" and "it is probably advisable to/not to" have clearly distinct meanings for users.

\section{Competing interests}

The authors declare that they have no competing interests.

Received: 31 August 2015 Accepted: 26 January 2016

Published online: 16 February 2016

\section{References}

1. Levy B, Bastien O, Benjelid K, Cariou A, Chouihed T, Combes A, et al. Experts' recommendations for the management of adult patients with cardiogenic shock. Ann Intensive Care. 2015;5(1):52.

2. Levy B, Bastien O, Karim B, Cariou A, Chouihed T, Combes A, et al. Erratum to: experts' recommendations for the management of adult patients with cardiogenic shock. Ann Intensive Care. 2015;5(1):26.

3. Fisher JD, Nelson DG, Beyersdorf H, Satkowiak LJ. Clinical spectrum of shock in the pediatric emergency department. Pediatr Emerg Care. 2010;26(9):622-5.

4. Singh D, Chopra A, Pooni PA, Bhatia RC. A clinical profile of shock in children in Punjab, India. Indian Pediatr. 2006;43(7):619-23.

5. Rossano JW, Kim JJ, Decker JA, Price JF, Zafar F, Graves DE, et al. Prevalence, morbidity, and mortality of heart failure-related hospitalizations in children in the United States: a population-based study. J Card Fail. 2012;18(6):459-70.

6. Webster G, Zhang J, Rosenthal D. Comparison of the epidemiology and co-morbidities of heart failure in the pediatric and adult populations: a retrospective, cross-sectional study. BMC Cardiovasc Disord. 2006;6:23.

7. Andrews RE, Fenton MJ, Ridout DA, Burch M. New-onset heart failure due to heart muscle disease in childhood: a prospective study in the United kingdom and Ireland. Circulation. 2008;117(1):79-84.

8. Massin MM, Astadicko I, Dessy H. Epidemiology of heart failure in a tertiary pediatric center. Clin Cardiol. 2008;31(8):388-91.

9. Saji T, Matsuura H, Hasegawa K, Nishikawa T, Yamamoto E, Ohki H, et al. Comparison of the clinical presentation, treatment, and outcome of fulminant and acute myocarditis in children. Circ J. 2012;76(5):1222-8.

10. Sommers $\mathrm{C}$, Nagel BH, Neudorf U, Schmaltz AA. Congestive heart failure in childhood. An epidemiologic study. Herz. 2005;30(7):652-62.

11. Biarent D, Bingham R, Eich C, Lopez-Herce J, Maconochie I, RodriguezNunez A, et al. European resuscitation council guidelines for resuscitation 2010 section 6. Paediatric life support. Resuscitation. 2010;81(10):1364-88.

12. Chaturvedi V, Saxena A. Heart failure in children: clinical aspect and management. Indian J Pediatr. 2009;76(2):195-205.

13. Kantor PF, Lougheed J, Dancea A, McGillion M, Barbosa N, Chan C, et al. Presentation, diagnosis, and medical management of heart failure in children: canadian cardiovascular society guidelines. Can J Cardiol. 2013;29(12):1535-52.

14. Wilkinson JD, Landy DC, Colan SD, Towbin JA, Sleeper LA, Orav EJ, et al. The pediatric cardiomyopathy registry and heart failure: key results from the first 15 years. Heart Fail Clin. 2010;6(4):401-13, vii.

15. Price JF, Mott AR, Dickerson HA, Jefferies JL, Nelson DP, Chang AC, et al. Worsening renal function in children hospitalized with decompensated heart failure: evidence for a pediatric cardiorenal syndrome? Pediatr Crit Care Med. 2008;9(3):279-84.

16. James $N$, Smith M. Treatment of heart failure in children. Curr Paediatr. 2005;15(7):539-48.

17. Rosenthal D, Chrisant MR, Edens E, Mahony L, Canter C, Colan S, et al. International Society for Heart and Lung Transplantation: practice guidelines for management of heart failure in children. J Heart Lung Transplant. 2004;23(12):1313-33.

18. Sandroni C, Nolan J. ERC 2010 guidelines for adult and pediatric resuscitation: summary of major changes. Minerva Anestesiol. $2011 ; 77(2): 220-6$.

19. Carcillo JA, Kuch BA, Han YY, Day S, Greenwald BM, McCloskey KA, et al. Mortality and functional morbidity after use of PALS/APLS by community physicians. Pediatrics. 2009;124(2):500-8.

20. Patterson MD, Boenning DA, Klein BL, Fuchs S, Smith KM, Hegenbarth MA, et al. The use of high-dose epinephrine for patients with out-ofhospital cardiopulmonary arrest refractory to prehospital interventions. Pediatr Emerg Care. 2005;21(4):227-37. 
21. Perondi MB, Reis AG, Paiva EF, Nadkarni VM, Berg RA. A comparison of high-dose and standard-dose epinephrine in children with cardiac arrest. N Engl J Med. 2004;350(17):1722-30.

22. de Oliveira CF, de Oliveira DS, Gottschald AF, Moura JD, Costa GA, Ventura AC, et al. ACCM/PALS haemodynamic support guidelines for paediatric septic shock: an outcomes comparison with and without monitoring central venous oxygen saturation. Intensive Care Med. 2008;34(6):1065-75.

23. Rivers E, Nguyen B, Havstad S, Ressler J, Muzzin A, Knoblich B, et al. Early goal-directed therapy in the treatment of severe sepsis and septic shock. N Engl J Med. 2001;345(19):1368-77.

24. Myburgh J, Finfer S. Causes of death after fluid bolus resuscitation: new insights from FEAST. BMC Med. 2013;11:67.

25. Mahle WT, Cuadrado AR, Kirshbom PM, Kanter KR, Simsic JM. Nesiritide in infants and children with congestive heart failure. Pediatr Crit Care Med. 2005;6(5):543-6.

26. Jefferies JL, Price JF, Denfield SW, Chang AC, Dreyer WJ, MCMahon CJ, et al. Safety and efficacy of nesiritide in pediatric heart failure. J Card Fail. 2007;13(7):541-8.

27. Regen RB, Gonzalez A, Zawodniak K, Leonard D, Quigley R, Barnes AP, et al. Tolvaptan increases serum sodium in pediatric patients with heart failure. Pediatr Cardiol. 2013;34(6):1463-8.

28. Strigl S, Beroukhim R, Valente AM, Annese D, Harrington JS, Geva T, et al. Feasibility of dobutamine stress cardiovascular magnetic resonance imaging in children. J Magn Reson Imaging. 2009;29(2):313-9.

29. Kwapisz MM, Neuhauser C, Scholz S, Welters ID, Lohr T, Koch T, et al. Hemodynamic effects of dobutamine and dopexamine after cardiopulmonary bypass in pediatric cardiac surgery. Paediatr Anaesth. 2009;19(9):862-71.

30. Razavi RS, Baker A, Qureshi SA, Rosenthal E, Marsh MJ, Leech SC, et al. Hemodynamic response to continuous infusion of dobutamine in Alagille's syndrome. Transplantation. 2001;72(5):823-8.

31. Booker PD, Evans C, Franks R. Comparison of the haemodynamic effects of dopamine and dobutamine in young children undergoing cardiac surgery. Br J Anaesth. 1995;74(4):419-23.

32. Mahoney L, Shah G, Crook D, Rojas-Anaya H, Rabe H. A literature review of the pharmacokinetics and pharmacodynamics of dobutamine in neonates. Pediatr Cardiol. 2015:37:14-23.

33. Barton P, Garcia J, Kouatli A, Kitchen L, Zorka A, Lindsay C, et al. Hemodynamic effects of i.v. milrinone lactate in pediatric patients with septic shock. A prospective, double-blinded, randomized, placebo-controlled, interventional study. Chest. 1996;109(5):1302-12.

34. Bailey JM, Miller BE, Lu W, Tosone SR, Kanter KR, Tam VK. The pharmacokinetics of milrinone in pediatric patients after cardiac surgery. Anesthesiology. 1999;90(4):1012-8.

35. Hoffman TM, Wernovsky G, Atz AM, Kulik TJ, Nelson DP, Chang AC, et al. Efficacy and safety of milrinone in preventing low cardiac output syndrome in infants and children after corrective surgery for congenital heart disease. Circulation. 2003;107(7):996-1002.

36. Lechner E, Hofer A, Leitner-Peneder G, Freynschlag R, Mair R, Weinzettel $R$, et al. Levosimendan versus milrinone in neonates and infants after corrective open-heart surgery: a pilot study. Pediatr Crit Care Med. 2012;13(5):542-8.

37. Namachivayam P, Crossland DS, Butt WW, Shekerdemian LS. Early experience with Levosimendan in children with ventricular dysfunction. Pediatr Crit Care Med. 2006;7(5):445-8.

38. Levy B, Perez P, Perny J, Thivilier C, Gerard A. Comparison of norepinephrine-dobutamine to epinephrine for hemodynamics, lactate metabolism, and organ function variables in cardiogenic shock. A prospective, randomized pilot study. Crit Care Med. 2011;39(3):450-5.

39. Meyer S, McGuire W, Gottschling S, Shamdeen GM, Gortner L. The role of vasopressin and terlipressin in catecholamine-resistant shock and cardio-circulatory arrest in children: review of the literature. Wien Med Wochenschr. 2011;161(7-8):192-203.

40. Mastropietro CW, Davalos MC, Seshadri S, Walters HL 3rd, Delius RE. Clinical response to arginine vasopressin therapy after paediatric cardiac surgery. Cardiol Young. 2013;23(3):387-93.

41. Matok I, Rubinshtein M, Levy A, Vardi A, Leibovitch L, Mishali D, et al. Terlipressin for children with extremely low cardiac output after open heart surgery. Ann Pharmacother. 2009;43(3):423-9.
42. Jerath N, Frndova H, McCrindle BW, Gurofsky R, Humpl T. Clinical impact of vasopressin infusion on hemodynamics, liver and renal function in pediatric patients. Intensive Care Med. 2008;34(7):1274-80.

43. Mastropietro CW, Clark JA, Delius RE, Walters HL 3rd, Sarnaik AP. Arginine vasopressin to manage hypoxemic infants after stage I palliation of single ventricle lesions. Pediatr Crit Care Med. 2008;9(5):506-10.

44. Duncan JM, Meaney P, Simpson P, Berg RA, Nadkarni V, Schexnayder S. Vasopressin for in-hospital pediatric cardiac arrest: results from the American Heart Association National Registry of Cardiopulmonary Resuscitation. Pediatr Crit Care Med. 2009;10(2):191-5.

45. Appelbaum A, Blackstone EH, Kouchoukos NT, Kirklin JW. Afterload reduction and cardiac ouptut in infants early after intracardiac surgery. Am J Cardiol. 1977;39(3):445-51.

46. Benzing G 3rd, Helmsworth JA, Schrieber JT, Loggie J, Kaplan S. Nitroprusside after open-heart surgery. Circulation. 1976;54(3):467-71.

47. Dillon TR, Janos GG, Meyer RA, Benzing G 3rd, Kaplan S. Vasodilator therapy for congestive heart failure. J Pediatr. 1980;96(4):623-9.

48. Frobel AK, Hulpke-Wette M, Schmidt KG, Laer S. Beta-blockers for congestive heart failure in children. Cochrane Database Syst Rev. 2009;(1):CD007037.

49. Chang PM, Silka MJ, Moromisato DY, Bar-Cohen Y. Amiodarone versus procainamide for the acute treatment of recurrent supraventricular tachycardia in pediatric patients. Circ Arrhythm Electrophysiol. 2010;3(2):134-40.

50. Robinson J, Hartling L, Vandermeer B, Crumley E, Klassen TP. Intravenous immunoglobulin for presumed viral myocarditis in children and adults. Cochrane Database Syst Rev. 2005;(1):CD004370.

51. Kim HJ, Yoo GH, Kil HR. Clinical outcome of acute myocarditis in children according to treatment modalities. Korean J Pediatr. 2010;53(7):745-52.

52. Hia CP, Yip WC, Tai BC, Quek SC. Immunosuppressive therapy in acute myocarditis: an 18 year systematic review. Arch Dis Child. 2004:89(6):580-4.

53. Aziz KU, Patel N, Sadullah T, Tasneem H, Thawerani H, Talpur S. Acute viral myocarditis: role of immunosuppression: a prospective randomised study. Cardiol Young. 2010;20(5):509-15.

54. Camargo PR, Snitcowsky R, da Luz PL, Mazzieri R, Higuchi ML, Rati $M$, et al. Favorable effects of immunosuppressive therapy in children with dilated cardiomyopathy and active myocarditis. Pediatr Cardiol. 1995;16(2):61-8

55. Gupta P, Kuperstock JE, Hashmi S, Arnolde V, Gossett JM, Prodhan P, et al. Efficacy and predictors of success of noninvasive ventilation for prevention of extubation failure in critically ill children with heart disease. Pediatr Cardiol. 2013;34(4):964-77.

56. Odena MP, Marimbaldo IP, Matute SS, Argallo MB, Rico AP. Aplicacion de ventilacion no invasiva en pacientes postoperados cardiacos. Estudio retrospectivo. An Pediatr (Barc). 2009;71(1):13-9.

57. Yildizdas D, Yilmaz HL, Erdem S. Treatment of cardiogenic pulmonary oedema by helmet-delivered non-invasive pressure support ventilation in children with scorpion sting envenomation. Ann Acad Med Singapore. 2008;37(3):230-4.

58. Bacha EA, Zimmerman FJ, Mor-Avi V, Weinert L, Starr JP, Sugeng L, et al. Ventricular resynchronization by multisite pacing improves myocardial performance in the postoperative single-ventricle patient. Ann Thorac Surg. 2004;78(5):1678-83.

59. Dubin AM, Janousek J, Rhee E, Strieper MJ, Cecchin F, Law $\Vdash H$, et al. Resynchronization therapy in pediatric and congenital heart disease patients: an international multicenter study. J Am Coll Cardiol. 2005:46(12):2277-83.

60. Janousek J, Gebauer RA, Abdul-Khaliq H, Turner M, Kornyei L, Grollmuss $\mathrm{O}$, et al. Cardiac resynchronisation therapy in paediatric and congenital heart disease: differential effects in various anatomical and functional substrates. Heart. 2009;95(14):1165-71.

61. Janousek J, Vojtovic P, Hucin B, Tlaskal T, Gebauer RA, Gebauer R, et al. Resynchronization pacing is a useful adjunct to the management of acute heart failure after surgery for congenital heart defects. Am J Cardiol. 2001;88(2):145-52.

62. Zimmerman FJ, Starr JP, Koenig PR, Smith P, Hijazi ZM, Bacha EA. Acute hemodynamic benefit of multisite ventricular pacing after congenital heart surgery. Ann Thorac Surg. 2003;75(6):1775-80. 
63. Biarent D, Bourdages M, Berner M, Miro J, van Doesburg NH, Toledano B. Choc Cardiogénique. In: Lacroix J, Gauthier M, Hubert P, Leclerc F, Gaudreault P, editors. Urgences et soins intensifs pediatriques. Masson: Edition du Sainte Justine et Elsevier; 2007. p. 187-210.

64. Kantor PF, Mertens LL. Clinical practice: heart failure in children. Part II: current maintenance therapy and new therapeutic approaches. Eur J Pediatr. 2010;169(4):403-10.

65. Kim JJ, Rossano JW, Nelson DP, Price JF, Dreyer WJ. Heart failure in infants and children: etiology, pathophysiology, and diagnosis of heart failure. In: Nichols DG, editor. Roger's textbook of pediatric intensive care. Philadelphia: Wolters Kluwer/Lippincott, Williams \& Wilkins; 2008. p. 1064-74.

66. Zingarelli B. Shock and reperfusion. In: Nichols DG, editor. Roger's textbook of pediatric intensive care. Philadelphia: Wolters Kluwer/Lippincott, Williams \& Wilkins; 2008. p. 252-61.

67. Dellinger RP, Levy MM, Carlet JM, Bion J, Parker MM, Jaeschke R, et al. Surviving Sepsis Campaign: international guidelines for management of severe sepsis and septic shock: 2008. Crit Care Med. 2008;36(1):296-327.

68. Duke TD, Butt W, South M. Predictors of mortality and multiple organ failure in children with sepsis. Intensive Care Med. 1997;23(6):684-92.

69. Hatherill M, McIntyre AG, Wattie M, Murdoch IA. Early hyperlactataemia in critically ill children. Intensive Care Med. 2000;26(3):314-8.

70. Halley GC, Tibby S. Hemodynamic monitoring. In: Nichols DG, editor. Roger's textbook of pediatric intensive care. Philadelphia: Wolters Kluwer/Lippincott, Williams \& Wilkins; 2008. p. 1039-63.

71. Babuin L, Jaffe AS. Troponin: the biomarker of choice for the detection of cardiac injury. CMAJ. 2005;173(10):1191-202.

72. Checchia PA, Moynihan JA, Brown L. Cardiac troponin I as a predictor of mortality for pediatric submersion injuries requiring out-of-hospital cardiopulmonary resuscitation. Pediatr Emerg Care. 2006;22(4):222-5.

73. Kantor PF, Rusconi P, Lipshultz S, Mital S, Wilkinson JD, Burch M. Current applications and future needs for biomarkers in pediatric cardiomyopathy and heart failure: summary from the second international conference on pediatric cardiomyopathy. Prog Pediatr Cardiol. 2011;32(1):11-4.

74. Sugimoto M, Manabe H, Nakau K, Furuya A, Okushima K, Fujiyasu $\mathrm{H}$, et al. The role of $\mathrm{N}$-terminal pro-B-type natriuretic peptide in the diagnosis of congestive heart failure in children-correlation with the heart failure score and comparison with B-type natriuretic peptide. Circ J. 2010;74(5):998-1005.

75. Gessler P, Knirsch W, Schmitt B, Rousson V, von Eckardstein A. Prognostic value of plasma $\mathrm{N}$-terminal pro-brain natriuretic peptide in children with congenital heart defects and open-heart surgery. J Pediatr. 2006;148(3):372-6.

76. Nir A, Lindinger A, Rauh M, Bar-Oz B, Laer S, Schwachtgen L, et al. NT-pro-B-type natriuretic peptide in infants and children: reference values based on combined data from four studies. Pediatr Cardiol. 2009;30(1):3-8.

77. Cohen S, Springer C, Avital A, Perles Z, Rein AJ, Argaman Z, et al. Aminoterminal pro-brain-type natriuretic peptide: heart or lung disease in pediatric respiratory distress? Pediatrics. 2005;115(5):1347-50.

78. Koglin J, Pehlivanli S, Schwaiblmair M, Vogeser M, Cremer P, vonScheidt W. Role of brain natriuretic peptide in risk stratification of patients with congestive heart failure. J Am Coll Cardiol. 2001;38(7):1934-41.

79. Pottecher J, Bouzou G, Van de Louw A. Monitorage de la saturation de pouls: intérêts et limites. Réanimation. 2003;12:30-6.

80. Marino BS, Kaltman JR, Tanel RE. Cardiac conduction, dysrythmia, and pacing. In: Nichols DG, editor. Roger's textbook of pediatric intensive care. Philadelphia: Wolters Kluwer/Lippincott, Williams \& Wilkins; 2008. p. 1126-49.

81. Breinholt JP, Nelson DP, Towbin JA. Heart failure in infants and children: cardiomyopathy. In: Nichols DG, editor. Roger's textbook of pediatric intensive care. Philadelphia: Wolters Kluwer/Lippincott, Williams \& Wilkins; 2008. p. 1082-92.

82. Dannevig I, Dale HC, Liestol K, Lindemann R. Blood pressure in the neonate: three non-invasive oscillometric pressure monitors compared with invasively measured blood pressure. Acta Paediatr. 2005;94(2):191-6.
83. Chantepie A, Gold F. Physiologie et pathologie circulatoires. In: AmielTison C, Cabrol D, editors. Foetus et nouveau-né de faible poids. 2ième ed. Masson, Paris: Collection de la périnatalité. 2000. p. 63-83.

84. Clark JA, Lieh-Lai MW, Sarnaik A, Mattoo TK. Discrepancies between direct and indirect blood pressure measurements using various recommendations for arm cuff selection. Pediatrics. 2002;110(5):920-3.

85. Dellinger RP, Levy MM, Rhodes A, Annane D, Gerlach H, Opal SM, et al. Surviving Sepsis Campaign: international guidelines for management of severe sepsis and septic shock, 2012. Intensive Care Med. 2013;39(2):165-228.

86. Sofer S, Zucker N, Bilenko N, Levitas A, Zalzstein E, Amichay D, et al. The importance of early bedside echocardiography in children with scorpion envenomation. Toxicon. 2013;68:1-8.

87. Joseph MX, Disney PJ, Da Costa R, Hutchison SJ. Transthoracic echocardiography to identify or exclude cardiac cause of shock. Chest. 2004;126(5):1592-7.

88. Pershad J, Myers S, Plouman C, Rosson C, Elam K, Wan J, et al. Bedside limited echocardiography by the emergency physician is accurate during evaluation of the critically ill patient. Pediatrics. 2004;114(6):e667-71.

89. Spurney CF, Sable CA, Berger JT, Martin GR. Use of a hand-carried ultrasound device by critical care physicians for the diagnosis of pericardial effusions, decreased cardiac function, and left ventricular enlargement in pediatric patients. J Am Soc Echocardiogr. 2005;18(4):313-9.

90. Ruggiero A, De Rosa G, Rizzo D, Leo A, Maurizi P, De Nisco A, et al. Myocardial performance index and biochemical markers for early detection of doxorubicin-induced cardiotoxicity in children with acute Iymphoblastic leukaemia. Int J Clin Oncol. 2013;18(5):927-33.

91. Vignon P, Mucke F, Bellec F, Marin B, Croce J, Brouqui T, et al. Basic critical care echocardiography: validation of a curriculum dedicated to noncardiologist residents. Crit Care Med. 2011;39(4):636-42.

92. Creteur J. Monitorage de la saturation tissulaire musculaire en oxygène dans les états de choc. Réanimation. 2009;18:254-60.

93. Tobias JD, Russo P, Russo J. Changes in near infrared spectroscopy during deep hypothermic circulatory arrest. Ann Card Anaesth. 2009;12(1):17-21.

94. McQuillen PS, Nishimoto MS, Bottrell CL, Fineman LD, Hamrick SE, Glidden DV, et al. Regional and central venous oxygen saturation monitoring following pediatric cardiac surgery: concordance and association with clinical variables. Pediatr Crit Care Med. 2007;8(2):154-60.

95. Chakravarti SB, Mittnacht AJ, Katz JC, Nguyen K, Joashi U, Srivastava S. Multisite near-infrared spectroscopy predicts elevated blood lactate level in children after cardiac surgery. J Cardiothorac Vasc Anesth. 2009;23(5):663-7.

96. Kaufman J, Almodovar MC, Zuk J, Friesen RH. Correlation of abdominal site near-infrared spectroscopy with gastric tonometry in infants following surgery for congenital heart disease. Pediatr Crit Care Med. 2008;9(1):62-8.

97. Abramo T, Aggarwal N, Kane I, Crossman K, Meredith M. Cerebral oximetry and cerebral blood flow monitoring in 2 pediatric survivors with out-of-hospital cardiac arrest. Am J Emerg Med. 2014;32(4):394 e5-e10.

98. Nagdyman N, Fleck TP, Ewert P, Abdul-Khaliq H, Redlin M, Lange PE. Cerebral oxygenation measured by near-infrared spectroscopy during circulatory arrest and cardiopulmonary resuscitation. Br J Anaesth. 2003;91(3):438-42.

99. Rozé JC, Bigras JL. Surveillance cardiorespiratoire. In: Lacroix J, Gauthier M, Hubert P, Leclerc F, Gaudreault P, editors. Urgences et soins intensifs pediatriques. Masson: Edition du Sainte Justine et Elsevier; 2007. p. 3-33.

100. Ranucci M, Isgro G, De La Torre T, Romitti F, De Benedetti D, Carlucci $C$, et al. Continuous monitoring of central venous oxygen saturation (Pediasat) in pediatric patients undergoing cardiac surgery: a validation study of a new technology. J Cardiothorac Vasc Anesth. 2008:22(6):847-52.

101. Grissom CK, Morris AH, Lanken PN, Ancukiewicz M, Orme JF Jr, Schoenfeld DA, et al. Association of physical examination with pulmonary artery catheter parameters in acute lung injury. Crit Care Med. 2009;37(10):2720-6.

102. Walley KR. Use of central venous oxygen saturation to guide therapy. Am J Respir Crit Care Med. 2010;184:514-20. 
103. Skowno JJ, Broadhead M. Cardiac output measurement in pediatric anesthesia. Paediatr Anaesth. 2008;18(11):1019-28.

104. Sanchez O, Castelain V. Intérêt du cathétérisme cardiaque droit en réanimation. EMC (Elsevier Masson SAS, Paris). 2007; Pneumologie (6-040-P-30).

105. Lemson J, de Boode WP, Hopman JC, Singh SK, van der Hoeven JG. Validation of transpulmonary thermodilution cardiac output measurement in a pediatric animal model. Pediatr Crit Care Med. 2008;9(3):313-9.

106. Pauli C, Fakler U, Genz T, Hennig M, Lorenz HP, Hess J. Cardiac output determination in children: equivalence of the transpulmonary thermodilution method to the direct Fick principle. Intensive Care Med. 2002;28(7):947-52.

107. Tibby SM, Hatherill M, Marsh MJ, Morrison G, Anderson D, Murdoch IA. Clinical validation of cardiac output measurements using femoral artery thermodilution with direct Fick in ventilated children and infants. Intensive Care Med. 1997;23(9):987-91.

108. Kim JJ, Dreyer WJ, Chang AC, Breinholt JP 3rd, Grifka RG. Arterial pulse wave analysis: an accurate means of determining cardiac output in children. Pediatr Crit Care Med. 2006;7(6):532-5

109. del Nido PJ, Dalton HJ, Thompson AE, Siewers RD. Extracorporeal membrane oxygenator rescue in children during cardiac arrest after cardiac surgery. Circulation. 1992;86(5 Suppl):I1300-4.

110. Alsoufi B, Al-Radi OO, Nazer Rl, Gruenwald C, Foreman C, Williams WG, et al. Survival outcomes after rescue extracorporeal cardiopulmonary resuscitation in pediatric patients with refractory cardiac arrest. J Thorac Cardiovasc Surg. 2007;134(4):952-9 e2.

111. Alsoufi B, Awan A, Manlhiot C, Guechef A, Al-Halees Z, Al-Ahmadi $M$, et al. Results of rapid-response extracorporeal cardiopulmonary resuscitation in children with refractory cardiac arrest following cardiac surgery. Eur J Cardiothorac Surg. 2014;45(2):268-75.

112. Delmo Walter EM, Alexi-Meskishvili V, Huebler M, Redlin M, Boettcher W, Weng Y, et al. Rescue extracorporeal membrane oxygenation in children with refractory cardiac arrest. Interact CardioVasc Thorac Surg. 2011;12(6):929-34.

113. Duncan BW, Ibrahim AE, Hraska V, del Nido PJ, Laussen PC, Wessel DL, et al. Use of rapid-deployment extracorporeal membrane oxygenation for the resuscitation of pediatric patients with heart disease after cardiac arrest. J Thorac Cardiovasc Surg. 1998;116(2):305-11.

114. Huang SC, Wu ET, Wang CC, Chen YS, Chang Cl, Chiu IS, et al. Eleven years of experience with extracorporeal cardiopulmonary resuscitation for paediatric patients with in-hospital cardiac arrest. Resuscitation. 2012;83(6):710-4

115. Lowry AW, Morales DL, Graves DE, Knudson JD, Shamszad P, Mott AR, et al. Characterization of extracorporeal membrane oxygenation for pediatric cardiac arrest in the United States: analysis of the kids' inpatient database. Pediatr Cardiol. 2013;34(6):1422-30.

116. Matos Rl, Watson RS, Nadkarni VM, Huang HH, Berg RA, Meaney PA, et al. Duration of cardiopulmonary resuscitation and illness category impact survival and neurologic outcomes for in-hospital pediatric cardiac arrests. Circulation. 2013;127(4):442-51.

117. Ortmann L, Prodhan P, Gossett J, Schexnayder S, Berg R, Nadkarni V, et al. Outcomes after in-hospital cardiac arrest in children with cardiac disease: a report from Get With the Guidelines-Resuscitation. Circulation. 2011;124(21):2329-37.

118. Prodhan P, Fiser RT, Dyamenahalli U, Gossett J, Imamura M, Jaquiss RD, et al. Outcomes after extracorporeal cardiopulmonary resuscitation (ECPR) following refractory pediatric cardiac arrest in the intensive care unit. Resuscitation. 2009;80(10):1124-9.

119. Raymond TT, Cunnyngham CB, Thompson MT, Thomas JA, Dalton HJ, Nadkarni VM. Outcomes among neonates, infants, and children after extracorporeal cardiopulmonary resuscitation for refractory in hospital pediatric cardiac arrest: a report from the National Registry of Cardiopulmonary Resuscitation. Pediatr Crit Care Med. 2010;11(3):362-71.
120. Turek JW, Andersen ND, Lawson DS, Bonadonna D, Turley RS, Peters MA, et al. Outcomes before and after implementation of a pediatric rapidresponse extracorporeal membrane oxygenation program. Ann Thorac Surg. 2013;95(6):2140-6 (discussion 6-7).

121. Brown KL, Ichord R, Marino BS, Thiagarajan RR. Outcomes following extracorporeal membrane oxygenation in children with cardiac disease. Pediatr Crit Care Med. 2013;14(5 Suppl 1):S73-83.

122. Coskun KO, Coskun ST, Popov AF, Hinz J, El-Arousy M, Schmitto JD, et al. Extracorporeal life support in pediatric cardiac dysfunction. J Cardiothorac Surg. 2010;5:112.

123. Duncan BW, Bohn DJ, Atz AM, French JW, Laussen PC, Wessel DL. Mechanical circulatory support for the treatment of children with acute fulminant myocarditis. J Thorac Cardiovasc Surg. 2001;122(3):440-8.

124. Wilmot I, Morales DL, Price JF, Rossano JW, Kim JJ, Decker JA, et al. Effectiveness of mechanical circulatory support in children with acute fulminant and persistent myocarditis. J Card Fail. 2011;17(6):487-94.

125. Lequier $L$, Joffe $A R$, Robertson $C M$, Dinu IA, Wongswadiwat $Y$, Anton NR, et al. Two-year survival, mental, and motor outcomes after cardiac extracorporeal life support at less than five years of age. J Thorac Cardiovasc Surg. 2008;136(4):976-83 e3.

126. Kleinman ME, de Caen AR, Chameides L, Atkins DL, Berg RA, Berg MD, et al. Part 10: pediatric basic and advanced life support: 2010 international consensus on cardiopulmonary resuscitation and emergency cardiovascular care science with treatment recommendations. Circulation. 2010;122(16 Suppl 2):S466-515

127. Thiagarajan RR, Laussen PC, Rycus PT, Bartlett RH, Bratton SL. Extracorporeal membrane oxygenation to aid cardiopulmonary resuscitation in infants and children. Circulation. 2007;116(15):1693-700.

128. Tajik M, Cardarelli MG. Extracorporeal membrane oxygenation after cardiac arrest in children: what do we know? Eur J Cardiothorac Surg. 2008;33(3):409-17.

129. Haile DT, Schears GJ. Optimal time for initiating extracorporeal membrane oxygenation. Semin Cardiothorac Vasc Anesth. 2009;13(3):146-53.

130. Barrett CS, Bratton SL, Salvin JW, Laussen PC, Rycus PT, Thiagarajan RR. Neurological injury after extracorporeal membrane oxygenation use to aid pediatric cardiopulmonary resuscitation. Pediatr Crit Care Med. 2009;10(4):445-51.

131. Huang SC, Wu ET, Chen YS, Chang Cl, Chiu IS, Wang SS, et al. Extracorporeal membrane oxygenation rescue for cardiopulmonary resuscitation in pediatric patients. Crit Care Med. 2008;36(5):1607-13.

132. Trittenwein G, Pansi H, Graf B, Golej J, Burda G, Hermon M, et al. Proposed entry criteria for postoperative cardiac extracorporeal membrane oxygenation after pediatric open heart surgery. Artif Organs. 1999;23(11):1010-4.

133. Karamlou T, Vafaeezadeh M, Parrish AM, Cohen GA, Welke KF, Permut $L$, et al. Increased extracorporeal membrane oxygenation center case volume is associated with improved extracorporeal membrane oxygenation survival among pediatric patients. J Thorac Cardiovasc Surg. 2013;145(2):470-5.

\section{Submit your manuscript to a SpringerOpen ${ }^{\circ}$ journal and benefit from:}

- Convenient online submission

- Rigorous peer review

- Immediate publication on acceptance

- Open access: articles freely available online

- High visibility within the field

- Retaining the copyright to your article

Submit your next manuscript at springeropen.com 